\title{
Effect of Treated Distillery Effluent and Biocompost on Soil Phosphatase Activity in Paddy (Oryza sativa L.)
}

\author{
D. Leninraja $^{1 *}$, L. Chithra ${ }^{2}$, S. Maragatham ${ }^{3}$ and D. Balamurugan ${ }^{4}$
}

${ }^{1}(S S \& A C)$ - Agricultural College \& Research Institute, Tuticorin-628 252, Tamil Nadu, India

${ }^{2}$ (SS\&AC) - Sugarcane Research Station, Trichy-639 115, Tamil Nadu, India

${ }^{3}(S S \& A C)$ - Agricultural College \& Research Institute, Pudukkottai-622 104, TN, India

${ }^{4}(S S \& A C)$ - JKK Munirajah College of Agricultural Science, Erode- 638 506, TN, India

*Corresponding author

\begin{abstract}
A B S T R A C T
Keywords

Treated distillery effluent,

Biocompost, Paddy,

phosphatase activity,

Nutrient source, Yield

Article Info

Accepted:

12 September 2018

Available Online:

10 October 2018

In India, sugar industry is the second largest agro-based industry producing enormous quantities of by-products like molasses, pressmud etc. The Treated Distillery Effluent (TDE) is waste water, which could be recycled in agriculture both as irrigation water and as a source of plant nutrients. The beneficial effect of organic matter for enhancing the soil fertility and thereby improving the crop productivity is well established. Thus, the soil application of TDE could offer the double benefit of safe disposal of wastes and its effective utilization for agricultural production. A field experiment was conducted to study the effect of Treated Distillery Effluent (TDE) and biocompost on soil phosphatase activity using paddy as a test crop (ADT-43). The application of TDE @ 1.0 lakh litres ha ${ }^{-1}$ (M3) or TDE@1.5 lakh litres ha ${ }^{-1}$ (M4) along with $37.5 \% \mathrm{~N}$ as urea $+37.5 \% \mathrm{~N}$ as biocompost (S7) increased the soil phosphatase activity. Based on the increase in soil phosphatase activity, it can be concluded that TDE @ 1.0 lakh litres ha ${ }^{-1}$ (M3) or TDE @ 1.5 lakh litres $\mathrm{ha}^{-1}$ (M4) along with $37.5 \% \mathrm{~N}$ as urea $+37.5 \% \mathrm{~N}$ as biocompost (S7) can be recommended as a nutrient source for paddy crop.
\end{abstract}

\section{Introduction}

Application of TDE on soils is one of the most economical resources for the soil fertility amelioration through improvement in soil water holding capacity, texture, structure and nutrients retention. Now days in our country due to the increasing number of sugar mills and distillery units, application of distillery effluent on soil nearly become mandatory. These compounds may change soil physicochemical properties and soil enzyme activities.
Soil enzymes activities play an essential role in catalyzing reactions, which are necessary for the decomposition of organic matter and nutrient cycling in ecosystems, involving a range of plants, microorganisms, animals and their debris.

Therefore, changes in enzymes activity could alter the availability of nutrients for plant uptake and these changes are potentially sensitive indicators of soil quality. Therefore, the main objective of the present study was to 
evaluate the effect of different application rates of distillery effluent, on soil phosphatase activity.

\section{Materials and Methods}

Field experiment was conducted using paddy as a test crop (ADT-43). The experiment was conducted in a split plot design with four main plots viz., control; TDE @ 0.5 lakh litres ha ${ }^{-1}$; TDE@1.0 lakh litres ha ${ }^{-1}$; TDE@1.5 lakh litres ha ${ }^{-1}$. Different levels of $\mathrm{N}$ fertilizers viz., 100 per cent $\mathrm{N}$ as urea, 75 per cent $\mathrm{N}$ as urea, 100 per cent $\mathrm{N}$ as biocompost, 75 per cent $\mathrm{N}$ as biocompost, 75 per cent $\mathrm{N}$ as urea and 25 per cent $\mathrm{N}$ as biocompost, 37.5 per cent $\mathrm{N}$ as urea and 37.5 per cent $\mathrm{N}$ as biocompost and control were imposed as seven subplot treatments and the treatments were replicated twice. TDE was uniformly applied to each plot as per the treatment schedule at 45 days before planting.

The soil of the experimental field belong to Poovalur series (Typic haplustert), neutral in $\mathrm{pH}(\mathrm{pH} 7.58)$ and low in EC $\left(0.30 \mathrm{dSm}^{-1}\right)$. The organic carbon content $\left(4.00 \mathrm{~g} \mathrm{~kg}^{-1}\right)$ and the alkaline $\mathrm{KMnO}_{4}-\mathrm{N}\left(162 \mathrm{~kg} \mathrm{ha}^{-1}\right)$ were found to be low. The Olsen-P level $\left(16 \mathrm{~kg} \mathrm{ha}^{-1}\right)$ and the $\mathrm{NH}_{4} \mathrm{OAc}-\mathrm{K}\left(205 \mathrm{~kg} \mathrm{ha}^{-1}\right)$ were medium. The bacterial, fungal and actinomycetes population were found to be $10.2 \times 10^{6} \mathrm{CFU}$ $\mathrm{g}^{-1}$ of soil, $14 \times 10^{4} \mathrm{CFU} \mathrm{g} \mathrm{g}^{-1}$ of soil, $5.1 \times 10^{3}$ CFU $\mathrm{g}^{-1}$ of soil respectively. The phosphatase activity was found to be $2.5 \mu \mathrm{g}$ p-nitrophenol $\mathrm{g}^{-1}$ of soil hr-1 (Table 1).

\section{Phosphatase enzyme activity}

Five gram (w) of the fresh composite soil was taken in a boiling tube with $10 \mathrm{ml}$ distilled water. To this $0.25 \mathrm{ml}$ toluene and $1 \mathrm{ml} \mathrm{p}$ nitrophenol phosphate (PNPP) were added and incubated at room temperature for an hour. Then $5 \mathrm{ml}$ of $0.5 \mathrm{M}$ sodium chloride and 20 $\mathrm{ml}$ of $0.5 \mathrm{M}$ sodium hydroxide was added to the sample and filtered through Whatman No.42 filter paper. The colour intensity was read at $420 \mathrm{~nm}$ and the concentration of phosphatase $(\mathrm{X})$ in the sample was obtained from the standard graph (Tabatabai and Bremner, 1969).

\section{Statistical analysis}

The data on various characters studied during the investigation were statistically analyzed by the method given by Gomez and Gomez (1984). The critical difference was worked out at 5 per cent $(0.05)$ probability levels.

\section{Results and Discussion}

The impact of TDE and biocompost as well as the different levels of fertilizers on soil phosphatase activity was very well pronounced and the results are as follows.

Soil phosphatase activity as influenced by different levels of TDE and biocompost (Table 2)

Enzyme activity in soil is an indirect indication of the microbial activity, which is directly correlated with soil microbial population.

In the present investigation, greater activity of phosphatase was associated with the TDE application.

Application of TDE and biocompost significantly increased the soil phosphatase activity. Among the main plot treatments, application of TDE @ 1.5 lakh litres ha ${ }^{-1}$ (M4) recorded highest phosphatase activity of 2.31 $\mu \mathrm{g}$ p-nitrophenol $\mathrm{g}^{-1}$ dry soil $\mathrm{hr}^{-1}$ being on par with the application of TDE @ 1.0 lakh litres $\mathrm{ha}^{-1}$ (M3) recording $2.27 \mu \mathrm{g}$ p-nitrophenol g ${ }^{-1}$ dry soil $\mathrm{hr}^{-1}$. The control (S1) recorded lowest phosphatase activity of $1.40 \mu \mathrm{g}$ p-nitrophenol $\mathrm{g}^{-1}$ dry soil $\mathrm{hr}^{-1}$. 
Table.1 Characteristics of Initial Soil

\begin{tabular}{|c|c|}
\hline Parameters & Values \\
\hline \multicolumn{2}{|l|}{ 1. Mechanical composition } \\
\hline Textural class & Sandy Clay \\
\hline Soil series & Poovalur Series \\
\hline Soil taxonomy & Typic haplustert \\
\hline \multicolumn{2}{|l|}{ 2.Chemical composition } \\
\hline pH (1: 2.5 soil water suspension) & 7.58 \\
\hline $\mathrm{EC}\left(\mathrm{dSm}^{-1}\right)(1: 2.5$ soil water extract $)$ & 0.30 \\
\hline Organic carbon $\left(\mathrm{g} \mathrm{kg}^{-1}\right)$ & 4.00 \\
\hline $\mathrm{KMnO}_{4}-\mathbf{N}\left(\mathrm{kg} \mathrm{ha}^{-1}\right)$ & 162 \\
\hline Olsen - P $\left(\mathrm{kg} \mathrm{ha}^{-1}\right)$ & 16 \\
\hline $\mathrm{NH}_{4} \mathrm{OAc}-\mathrm{K}\left(\mathrm{kg} \mathrm{ha}^{-1}\right)$ & 205 \\
\hline \multicolumn{2}{|l|}{ 3.Biological properties } \\
\hline Bacteria (x 10 ${ }^{6} \mathrm{CFU} \mathrm{g}^{-1}$ of soil) & 10.2 \\
\hline Fungi (x 10 ${ }^{4} \mathrm{CFU} \mathrm{g}^{-1}$ of soil) & 14.0 \\
\hline 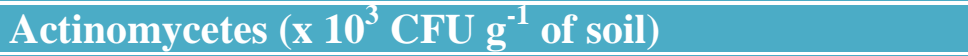 & 5.1 \\
\hline Phosphatase activity ( $\mu \mathrm{g}$ p-nitrophenol $\mathrm{g}^{-1}$ of soil $\mathrm{hr}^{-1}$ ) & 2.5 \\
\hline
\end{tabular}

Table.2 Soil phosphatase activity as influenced by different levels of tde and biocompost

\begin{tabular}{|c|c|c|c|c|c|c|c|c|}
\hline \multirow[t]{2}{*}{ Treatments } & \multicolumn{8}{|c|}{ Phosphatase activity ( $\mu \mathrm{g}$ p-nitrophenol $\mathrm{g}^{-1}$ soil $\mathrm{hr}^{-1}$ ) } \\
\hline & S1 & $\mathbf{S 2}$ & S3 & S4 & S5 & S6 & S7 & Mean \\
\hline M1 & 1.27 & 1.45 & 1.43 & 1.40 & 1.38 & 1.49 & 1.41 & 1.40 \\
\hline M2 & 1.81 & 1.95 & 1.95 & 1.90 & 1.88 & 1.99 & 1.93 & 1.92 \\
\hline M3 & 2.10 & 2.31 & 2.28 & 2.21 & 2.17 & 2.36 & 2.44 & 2.27 \\
\hline M4 & 2.21 & 2.32 & 2.34 & 2.28 & 2.25 & 2.38 & 2.40 & 2.31 \\
\hline Mean & 1.85 & 2.01 & 2.00 & 1.95 & 1.92 & 2.06 & 2.04 & 1.97 \\
\hline & & & $\mathbf{M}$ & $\mathbf{S}$ & M at S & S at $M$ & & \\
\hline & & SEd & 0.03 & 0.01 & 0.03 & 0.01 & & \\
\hline & & $\mathrm{D}(5 \%)$ & 0.10 & 0.02 & 0.10 & 0.02 & & \\
\hline
\end{tabular}

M1 - Control; M2 - application of TDE @ 0.5 lakh litres ha ${ }^{-1}$; M3 - application of TDE @ 1.0 lakh litres ha ${ }^{-1}$; M4 - application of TDE @ 1.5 lakh litres ha ${ }^{-1}$

S1 - Control; S2- $100 \% \mathrm{~N}$ as urea; S3 - $75 \% \mathrm{~N}$ as urea; S4- $100 \% \mathrm{~N}$ as biocompost; S5- 75 $\% \mathrm{~N}$ as biocompost;

S6 - $75 \% \mathrm{~N}$ as urea and $25 \% \mathrm{~N}$ as biocompost;S7 - $37.5 \% \mathrm{~N}$ as urea and $37.5 \% \mathrm{~N}$ as biocompost 
The TDE being liquid organic manure increased the organic matter and nutrients content of the soil and subsequently enhanced the microbial biomass.

The high dose of TDE along with the recommended dose of NPK recorded the highest value. It implies that organic and inorganic nutrient inputs provided a nutrient rich environment, which is essential for the development of microbes and synthesis of enzymes.

Engracia Madejon et al., (2003) found a positive correlation between the organic residues and dehydrogenase, $\beta$-glucosidase, urease and protease activities of the soil.

Ramana et al., (2002) also reported that the enzyme activities were increased due to the application of distillery effluent.

Generally, organic manure addition was found to enhance the microbial activities which in turn favoured the synthesis of various enzymes in soil.

These three enzymes play a significant role in the bio-transformation of nutrients in soil, and thus influence the nutrients availability in soil and uptake by crops. The mineralization rate of organic $\mathrm{P}$ is relevant to both $\mathrm{P}$ nutrition of crops and phosphatase activity in soil.

Therefore, higher enzyme activities in soil suggested that the mineralization of $\mathrm{N}$ and $\mathrm{P}$ was greater due to the application of spent wash. Similar results was reported by Dinesh (2011) and Previna (2012).

Among the $\mathrm{N}$ fertilizer levels, $\mathrm{S} 6(75 \% \mathrm{~N}$ as urea $+25 \% \mathrm{~N}$ as biocompost) recorded higher phosphatase activity of $2.06 \mu \mathrm{g}$ p-nitrophenol g ${ }^{-1}$ dry soil $\mathrm{hr}^{-1}$ which was being comparable with S7
(37.5\% $\mathrm{N}$ as urea $+37.5 \% \mathrm{~N}$ as biocompost) recording $2.04 \mu \mathrm{g}$ p-nitrophenol $\mathrm{g}^{-1}$ dry soil $\mathrm{hr}^{-1}$. The interaction effect of $\mathrm{M} \times \mathrm{S}$ treatment was found to be significant. Application of TDE @ 1.0 lakh litres $\mathrm{ha}^{-1}$ along with $37.5 \% \mathrm{~N}$ as urea + $37.5 \% \mathrm{~N}$ as biocompost (M3S7) recorded higher phosphatase activity of $2.44 \mu \mathrm{g}$ p-nitrophenol gdry soil $\mathrm{hr}^{-1}$ followed by the application of TDE @ 1.5 lakh litres $\mathrm{ha}^{-1}$ along with $37.5 \% \mathrm{~N}$ as urea $+37.5 \% \mathrm{~N}$ as biocompost (M4S7) recording higher phosphatase activity of $2.40 \mu \mathrm{g} \quad$ nitrophenol $\mathrm{g}^{-1}$ dry soil $\mathrm{hr}^{-1}$.

\section{References}

Dinesh, D. 2011. Utilization of distillery industrial wastes as sources of nutrients for maize (Zea mays L.). Ph.D. Thesis, Tamil Nadu Agricultural University, Coimbatore.

Engracia Madejon S, Burgos P, Lopez R and Cabrera F. 2003. Agricultural use of three organic residues: effect on orange production and on properties of a soil of Spain. Nutrient Cycl. Agroecosyst., 65: 281-288.

Gomez, K. A and Gomez, A. A. 1984. Statistical Procedures for Agricultural Research, Pub: John Wiley and Sons, New Delhi. Pp. 680.

Previna, S. 2012. Ecofriendly utilization of Treated Distillery Effluent (TDE) on sugarcane (Saccharum officinarum L.) Ph.D. Thesis, Tamil Nadu Agricultural University, Coimbatore.

Ramana, S., Biswas, A. K., Kundu, S., Sana, J. K. and Yadava, R. B. R. 2002. Effect of distillery effluent on seed germination in some vegetable crops. Bioresource Technol., 82: 273-275.

Tabatabai, M. A and M. J. Bremner. 1969. Use of p-nitrophenol phosphate for assay of soil phosphatase activity. Soil Biol. Biochem., 1: 301-307.

\section{How to cite this article:}

Leninraja, D., L. Chithra, S. Maragatham and Balamurugan, D. 2018. Effect of Treated Distillery Effluent and Biocompost on Soil Phosphatase Activity in Paddy (Oryza sativa L.). Int.J.Curr.Microbiol.App.Sci. 7(10): 1651-1654. doi: https://doi.org/10.20546/ijcmas.2018.710.188 